\title{
Effect of Hoof Trimming on Milk Yield in Dairy Cows with Foot Disease
}

\author{
Murat Kibar' \& Tamer Çağlayan²
}

\begin{abstract}
Backround: Milk is produced at the cost of other metabolic processes in the body and high milk yield has been associated with lameness and claw lesions. Lameness has also been associated with a decrease in milk yield. In the past, claw disorders and lameness in dairy cattle have been an increasing problem of the modern dairy industry. Hoof trimming is performed to prevent hoof lesions and improve gait by correction and maintenance of the hoof symmetry and shape. Lameness caused by hoof disorders can be treated by correct hoof trimming. The aim of this study was to test the hypothesis that one-time claw trimming affect the milk production in dairy cattle with hoof disorders on commercial dairy farms.

Materials, Methods \& Results: Milk yield level was examined before and after claw trimming in dairy cattle. Eighteen Holstein dairy cows were examined on a commercial dairy farm. Calving number, calving time, lactation number, lactation stage, culling date and milk yield in liters were detected from farm recording system. All cows were visual signs of claw disorders or lameness. Their hooves had not been were trimmed for several years. Trimming technique included leveling the 2 claws, aiming for symmetric bulbs. The axial and abaxial walls were both intended to be parts of the bearing surface and the 2 claws were trimmed flat and balanced with each other. The caudal two-thirds of the axial sole of both claws were sloped toward the interdigital area. All of the cows checked for hoof diseases. The period of observation spanned $45 \mathrm{~d}$, starting day of claw trimming. The observation period was the lactation when the claw trimming was performed. Milk yield was performed one day before and 10,30, and 45 days after hoof trimming. Cows that were in the mid to late lactation period were selected for the study. The mean days in milk for the group was 221.8 (150-272 days) and the mean number of calvings was 2.8 times (range: 2-5 times) before trimming.

Discussion: The shape of the lactation curve is influenced by herd factors such as management and nutrition and individual factors like genetics, parity, and disease. Discrepancies in the literature with regard to the effect of lameness and claw lesions on milk yield are partly the result of these complex influences. Daily milk production of cows in the current study averaged $21 \mathrm{~L} / \mathrm{d}$, so milk weight represented approximately $3 \%$ of a cow's body weight per milking. In this study cows were 2 to 5th lactation. Most hoof diseases are accrued around the time of calving. Hoof diseases is becomed visible on the bearing surface of the sole after 2 to 3 months such as white-line disease, sole ulcer, and hemorrhages. We assessed milk yield as the one time claw trimming performed, so any possible healing effect of claw trimming could have led to an underestimation of any negative effects of bad claw health on milk production. Cows with painful claw lesions eat less, are more reluctant to move, and might consequently produce less milk than cows without claw lesions. The significant associations between most claw disorders and increased yield in this study do not prove direct relationships. At claw trimming, the average lactation stage in first parity was 148 DIM; $25 \%$ of the cows were before 74 DIM and $25 \%$ were later than 226 DIM. After the claw trimming between days $10-30$ and $10-45$ were determined differences in milk yield $(P<0.05$; $P<0.01$ ). In conclusion, this study showed that one time hoof trimming during the lactation period changed the milk yield of the dairy cows with hoof diseases.
\end{abstract}

Keywords: claw trimming, cow, milk yield. 


\section{INTRODUCTION}

Milk is produced at the cost of other metabolic processes in the body and high milk yield has been associated with lameness and claw lesions [2,16,24]. Lameness has also been associated with a decrease in milk yield [15,24]. Milk yield is decreased linearly as locomotion score increased [3,17]. Due to their economic impact $[8,19]$, claw disorders in dairy cattle is receiving as much attention as fertility or mastitis. Decline in milk yield is start up to 2 week before lameness was diagnosed [26]. Decrease in milk yield after a lameness episode is persisted for 4 month [12]. In the past, claw disorders and lameness in dairy cattle have been an increasing problem of the modern dairy industry $[27,28]$. With increases in the incidence of hoof and leg injuries and disease, research on dairy cattle lameness has grown considerably over the last 25 years $[5,10]$.

Lameness causes reduced animal welfare and is among the 3 most loss-making diseases in the dairy industry after mastitis and fertility problems $[18,24]$. Therefore, there is an increasing awareness of the importance of hoof trimming. Hoof trimming is performed to prevent hoof lesions and improve gait by correction and maintenance of the hoof symmetry and shape, which ensures correct weight bearing. Lameness caused by hoof disorders can be treated by correct hoof trimming $[20,22]$. Trimming in healthy hooves is significantly effected on milk fat and milk protein compositions [21].

The objective of this study was to test the hypothesis that one-time claw trimming affect the milk production in dairy cattle with hoof disorders on commercial dairy farms. Milk yield level was examined before and after claw trimming in dairy cattle.

\section{MATERIALS AND METHODS}

Eighteen Holstein dairy cows (age $=4.5 \pm 1.0$ yr; weight $=692 \pm 118 \mathrm{~kg}$ ) were examined on a commercial dairy farm. Cows were housed in free-stalls. All animals were multiparous cow. Calving number, calving time, lactation number, lactation stage, culling date and milk yield in liters were detected from farm recording system. All cows were visual signs of claw disorders or lameness.

They were housed in tie-stall barns for separate feeding all day long and therefore had no exercise. The walking areas were cleaned automatically

every 20 min via a manure scraper. Their hooves had not been were trimmed for several years. The hooves were trimmed by an experienced claw trimmer (M.K). Trimming technique included leveling the 2 claws, aiming for symmetric bulbs. The axial and abaxial walls were both intended to be parts of the bearing surface and the 2 claws were trimmed flat and balanced with each other. The caudal two-thirds of the axial sole of both claws were sloped toward the interdigital area. All of the cows checked for hoof diseases such as sole hemorrhage ( $\mathrm{SH})$, sole ulcer (SU), interdigital dermatitis (IDD), digital dermatitis (DD), and white line disease (WD). Incidence of these disorders was determined. Lameness were scored as sound (1), slightly uneven gait (2), lame (3), very lame (4), and extremely lame (5).

The period of observation spanned $45 \mathrm{~d}$, starting day of claw trimming. The observation period was the lactation when the claw trimming was performed. To allow the cows to adapt to their trimmed claws, a second series of milk yield controlled in 10th, 30th, and 45 th days after trimming. Milk yield was performed one day before and 10,30 , and 45 days after hoof trimming. Five cows were excluded because of culling.

Cows that were in the mid to late lactation period were selected for the study. The mean days in milk for the group was 221.8 (150-272 days) and the mean number of calvings was 2.8 times (range: $2-5$ times) before trimming. Cows were fed the same diet throughout the study. The average feed composition is listed in Table 1.

Shapiro-Wilk W test for normality control were applied to the data. The data were analyzed by SPSS (version 15.0) utilizing General Linear Model Repeated Measures. The Paired $t$-test was used to analyze the results before and after hoof trimming.

Table 1. The composition of ration used in the study.

\begin{tabular}{cc}
\hline Ingredient & Daily quantity - kg / cow \\
\hline Wheat hay & 6 \\
Alfalfa hay & 4 \\
Barley & 4 \\
Cottonseed meal & 2 \\
Wheat bran & 1 \\
Sugar beet pulp & 15 \\
Limestone & 0.1 \\
Salt & 0.04 \\
Vitamin-mineral premix* & 0.03 \\
*Provided per 1 kg of premix: Vit. A 15000000 IU, Vit D3 3000000 IU, \\
Vit E 30000 mg, Mn 50000 mg, Zn 50000 mg, Fe 50000 mg, Cu 10000 \\
mg, I 800 mg, Co 150 mg, Se 150 mg.
\end{tabular}




\section{RESULTS}

At claw trimming, the average lactation stage in first parity was $148 \mathrm{DIM} ; 25 \%$ of the cows were before 74 DIM and 25\% were later than 226 DIM.

The lameness scores ranged from 3 (lame) to 5 (extremely lame). There were very few effects of level of milk production on lameness $(P>0.05)$. Lameness increased with age $(P<0.05)$. The effect of lactation number on these traits was apparent $(P<0.05)$.

Before hoof trimming, the average toe angle of forelimbs was $33.2 \pm 4.8^{\circ}$ (mean $\pm \mathrm{SD}$ ), and that of hind limbs was $35.7 \pm 5.2^{\circ}$. After trimming they were $42.1 \pm 3.2^{\circ}$ and $41.4 \pm 3.6^{\circ}$, respectively. These changes were statistically significant for both the forelimbs and hind limbs $(P<0.05)$.

Claw trimming, descriptive statistics on milk yield in terms of time are given in Table 2. Before and after the claw trimming, changes in milk yield by time is shown in Figure1. Tenth day milk yield after claw trimming increased by $0.88 \pm 0.55 \mathrm{~L}$ in cows compared with before trimming (Figure 1).
In this study, the mean incidences of $\mathrm{SH}$, SU, IDD, DD, and WD were 28.4\%, 19.1\%, 23.8\%, $18.3 \%$ and $10.4 \%$, respectively. Because the previous trimmings were not performed before, excessive overgrowth was present on claws.

After the claw trimming between days 10th30th and 10th-45th were determined differences $(P<$ $0.05 ; P<0.01)$ in milk yield in Table 3 .

The General Linear Model results applied to the data among times differences $(P=0.031)$ and intercept $(P=0.000)$ were significant $(P<0.05 ; P<$ $0.001)$. There was no significantly change in milk yield between before and after claw trimming. However, the milk yields were significantly significant between 10th and 30th, and 45th days.

Lameness and all claw lesions occurred at a higher frequency in hind claws than in front claws and analyses were performed only in hind claws.

According to Table 4, pair wise comparison to milk yield positive, and highly significant correlation were determined $(P<0.001)$.

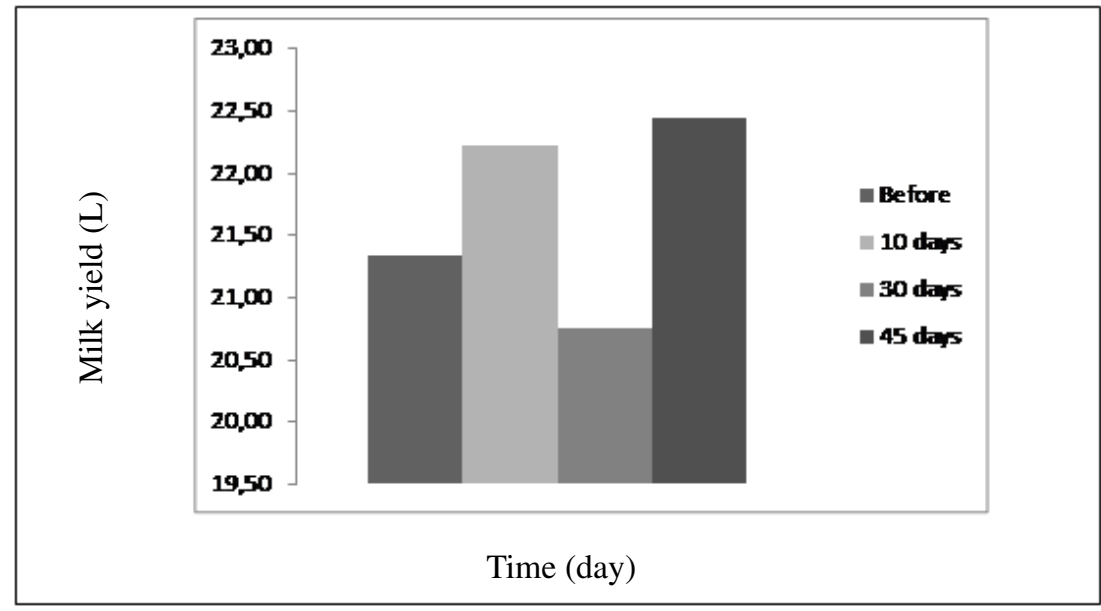

Figure 1. Changes to milk yield according to the time (Mean).

Table 2. Descriptive statistics on milk yield (L).

\begin{tabular}{ccccccc}
\hline Time & $\mathrm{n}$ & Min & Max & Mean & \pm & SE \\
\hline Before & 18 & 8.90 & 44.00 & 21.34 & \pm & 2.21 \\
10 days & 18 & 10.00 & 46.20 & 22.22 & \pm & 2.28 \\
30 days & 15 & 7.20 & 41.50 & 20.75 & \pm & 2.55 \\
45 days & 13 & 10.80 & 41.20 & 22.45 & \pm & 2.59 \\
\hline
\end{tabular}


Table 3. Comparison on effect of hoof trimming on milk yield*

\begin{tabular}{ccccccc}
\hline Pair & Time & $\mathrm{n}$ & Mean & \pm & SE & $\mathrm{P}$ \\
\hline Pair 1 & Before & 18 & 21.34 & \pm & 2.21 & 0.126 \\
& 10 days & 18 & 22.22 & \pm & 2.28 & \\
Pair 2 & Before & 15 & 21.86 & \pm & 2.58 & 0.067 \\
& 30 days & 15 & 20.75 & \pm & 2.55 & \\
Pair 3 & Before & 13 & 23.67 & \pm & 2.62 & 0.181 \\
& 45 days & 13 & 22.45 & \pm & 2.59 & \\
Pair 4 & 10 days & 15 & 22.99 & \pm & 2.66 & 0.009 \\
& 30 days & 15 & 20.75 & \pm & 2.55 & \\
Pair 5 & 10 days & 13 & 24.39 & \pm & 2.86 & 0.023 \\
& 45 days & 13 & 22.45 & \pm & 2.59 & \\
Pair 6 & 30 days & 13 & 22.55 & \pm & 2.58 & 0.879 \\
& 45 days & 13 & 22.45 & \pm & 2.59 & \\
\hline *Paired samples & statistics. & & & & &
\end{tabular}

Table 4. Paired samples correlations.

\begin{tabular}{ccccc}
\hline Pair & Time & $\mathrm{n}$ & Correlation & $P^{\#}$ \\
\hline Pair 1 & Before - 10 days & 18 & 0.971 & 0.000 \\
Pair 2 & Before - 30 days & 15 & 0.976 & 0.000 \\
Pair 3 & Before - 45 days & 13 & 0.945 & 0.000 \\
Pair 4 & 10 days - 30 days & 15 & 0.961 & 0.000 \\
Pair 5 & 10 days - 45 days & 13 & 0.967 & 0.000 \\
Pair 6 & 30 days - 45 days & 13 & 0.964 & 0.000 \\
${ }^{\# P<0.001 .}$ & & & &
\end{tabular}

\section{DISCUSSION}

The shape of the lactation curve is influenced by herd factors such as management and nutrition and individual factors like genetics, parity, and disease [24]. Discrepancies in the literature with regard to the effect of lameness and claw lesions on milk yield are partly the result of these complex influences. Daily milk production of cows in the current study averaged $21 \mathrm{~L} / \mathrm{d}$, so milk weight represented approximately $3 \%$ of a cow's body weight per milking. In contrast, the studies on horses and humans used relatively greater weights ( 15 to $20 \%$ of the subject's body weight) carried on the subject's back [14]. It is founded that high milk yield within the first third of lactation increases a cow's risk to experience health problems [6]. In this study cows were 2 to 5 th lactation.

Most hoof diseases are accrued around the time of calving. Hoof diseases is becomed visible on the bearing surface of the sole after 2 to 3 months such as white-line disease, sole ulcer, and hemorrhages $[24,29]$. We assessed milk yield as the one time claw trimming performed, so any possible healing effect of claw trimming could have led to an underestimation of any negative effects of bad claw health on milk production. This effect was partly accounted for by including the variable that described whether the test day was before claw trimming, 10th, 30th, and 45th days later. Milk yield is analyzed in the previous lactation to avoid direct relationships between lameness and milk yield within the same lactation [4,24]. Further research is needed to evaluate if milk yield is also related to the timing of claw trimming during the lactation. Cows with low milk yield [24] and lameness and claw lesions are more likely to be culled [23,24]. This is particularly problematic with lameness and claw lesions, because these disorders occur throughout the lactation (but usually around calving). Cows with high milk yield stay in the herd longer and have an increased chance of experiencing claw and limb disorders, thus leading to an overestimation of the association between milk yield and such disorders. The cluster effect within herd was significant for all hind claw lesions, but was most marked for hemorrhage and solea ulcers in this study. 
Cows with painful claw lesions eat less, are more reluctant to move, and might consequently produce less milk than cows without claw lesions [9,24]. Reduction in milk yield associated with claw and limb disorders are likely to be caused by reductions in feed intake or increased energy consumption because of pain, which can also be present without visible lameness $[11,24]$. It is, however, unlikely that claw lesions that are not painful lead to decreases in milk yield. The significant associations between most claw disorders and increased yield in this study do not prove direct relationships.

It is indicated that a linear relationship between increasing degree of lameness and decreasing milk yield among cows in second and later lactations [15]. It is reported that milk yield decreased linearly as locomotion score increased $[3,17]$. It is founded that no differences in the incidence of claw and feet problems in high yielding vs. average-yielding cows and concluded that with adequate husbandry, management, and feeding, cows yielding $>45 \mathrm{~kg} / \mathrm{d}$ can be maintained without more serious problems than cows yielding $35 \mathrm{~kg} / \mathrm{d}$ [1]. It is founded that milk production at the onset of foot lesions was a determining factor of the amount and pattern of milk loss, but only for cases in mid to late lactation [7].

It is reported that mean incidences of digital dermatitis, solea ulcer, white line disease, and interdigital hyperplasia were $13.7 \%, 16.5 \%, 9.8 \%$, and $6.7 \%$, respectively [19]. These values nearly identical to those found in other studies [13,25]. In this study, the mean incidences of SH, SU, IDD, DD, and WD were $28.4 \%, 19.1 \%, 23.8 \%, 18.3 \%$ and $10.4 \%$, respectively, and there were substantial differences between herds.

It is reported that before hoof trimming, the average toe angle of forelimbs was $32.7^{\circ}$, and that of hind limbs was $35.2^{\circ}$ [21]. After trimming they were $41.5^{\circ}$ and $40.6^{\circ}$, respectively. It is also reported that the same values were $44.9^{\circ}$ in the forelimbs and $42.9^{\circ}$ in the hind limbs at second lactation in Holstein cows [13]. Cows had not been trimmed before; they hence had long hooves and acute toe angles. But after trimming, the toe angle was closer to these reported values, and the hoof shape was accurated.

Increased milk yield after claw trimming can be the result of well being and more comfortable walking and standing after trimming to correct claw shape and positive effects on different disorders. By measuring different blood parameters, it is concluded that cows began to eat more roughage after claw trimming [21], but in contrast to our study they did not detect higher milk yields after claw trimming. Milk yield is expected to decrease with increasing number of DIM after peak yield. Test days after claw trimming are in a later stage of lactation than test days before trimming; however, this was accounted for by adjusting milk yield according to DIM.

In the case of milk production and claw disorders in dairy cows, it seems sensible to postulate a lagged progressive path involving 3 traits. One path would describe the influence that test-day milk yield has on claw disorders, and the second path would pertain to the effect of the disorder on milk production level at the following test date.

\section{CONCLUSIONS}

In conclusion, this study showed that one time hoof trimming during the lactation period changed the milk yield of the dairy cows. In our opinion this change could be based on to increased comfortable walking after trimming. In this study, did not evaluated gait analyses, and hence would like to examine this control in future studies. The milk yield decreased in 10 days after trimming, but then it was increased and achieved to high level before trimming. That cows yielded more milk after claw trimming than before is an economic encouraging for routine claw trimming. Finally, hoof trimming may be priceless entity in the recovery of milk yield and suggestible in dairy cows.

Declaration of interest. The authors report no conflicts of interest. The authors alone are responsible for the content and writing of the paper.

\section{REFERENCES}

1 Aeberhard K., Bruckmaier R.M., Kuepfer U. \& Blum J.W. 2001. Milk yield and composition, nutrition, body conformation traits, body condition scores, fertility and diseases in high-yielding dairy cows-Part 1. Journal of Veterinary Medicine. 48(2): 97-110.

2 Alban L., Agger J.F. \& Lawson L.G. 1996. Lameness in tied Danish dairy cattle: The possible influence of housing systems, management, milk yield, and prior incidents of lameness. Preventive Veterinary Medicine. 29(2): 135-149. 
3 Bach A., Dinarés M., Devant M. \& Careé X. 2007. Associations between lameness and production, feeding and milking attendance of Holstein cows milked with an automatic milking system. Journal of Dairy Research. 74(1): 40-46.

4 Bielfeldt J.C., Badertscher R., Tölle K.H. \& Krieter J. 2005. Risk factors influencing lameness and claw disorders in dairy cows. Livestock Science. 95(3): 265-271.

5 Clarkson M.J., Downham D.Y., Faull W.B., Hughes J.W., Manson F.J., Merritt J.B., Murray R.D., Russell W.B., Sutherst J.E. \& Ward W.R. 1996. Incidence and prevalence of lameness in dairy cattle. Veterinary Record. 138(23): 563-567.

6 Collard B.L., Boettcher P.J., Dekkers J.C.M., Petitclerc D. \& Schaefferet L.R. 2000. Relationships between energy balance and health traits of dairy cattle in early lactation. Journal of Dairy Science. 83(11): 2683-2690.

7 Coulon J.B., Lescourret F. \& Fonty A. 1996. Effect of foot lesions on milk production by dairy cows. Journal of Dairy Science. 79(1): 44-49.

8 Entig H., Kooji D., Dijkhuizen A.A., Huirne R.B.M. \& Nordhuizen-Stassen E.N. 1997. Economic losses due to clinical lameness in dairy cattle. Livestock Science. 49(3): 259-267.

9 Fleischer P., Metzner M., Beyerbach M., Hoedemaker M. \& Klee W. 2001. The relationship between milk yield and the incidence of some diseases in dairy cows. Journal of Dairy Science. 84(9): 2025-2035.

10 Flower F.C., Sanderson D.J. \& Weary D.N. 2006. Effects of Milking on dairy cow gait. Journal of Dairy Science. 89(6): 2084-2089.

11 Fourichon C., Seegers H., Bareille N. \& Beaudeau F. 2001. Effects of disease on milk production in the dairy cow: A review. Journal of Dairy Science. 84(9): 2025-2035.

12 Green L., Hedges V.J., Schucken Y.H., Blowey R.W. \& Packington A.J. 2002. The impact of clinical lameness on milk yield of dairy cows. Journal of Dairy Science. 85(9): 2250-2256.

13 Hahn M.V., McDaniel B.T. \& Wilk J.C. 1984. Genetic and environmental variation of hoof characteristics of Holstein cattle. Journal of Dairy Science. 67(12): 2986-2998.

14 Haskell M.J., Rennie L.J., Bowell V.A. \& Lawrence A.B. 2006. Housing system, milk production, and zero-grazing effects on lameness and leg injury in dairy cows. Journal of Dairy Science. 89(11): 4259-4266.

15 Hernandez J.A., Garbarino E.J., Shearer J.K., Risco C.A. \& Thatcher W.W. 2005. Comparison of milk yield in dairy cows with different degrees of lameness. Journal of American Veterinary Medicine Association. 227(8): 12921296.

16 Hultgren J., Manske T. \& Bergsten C. 2004. Associations of sole ulcer at claw trimming with reproductive performance, udder health, milk yield, and culling in Swedish dairy cattle. Preventive Veterinary Medicine. 62(4): 233-251.

17 Juarez S.T., Robinson P.H., DePeters M. \& Price E. 2003. Impact of lameness on behavior and productivity of lactating Holstein cows. Applied Animal Behaviour Science. 83(1): 1-14.

18 Kossaibati M.A. \& Esslemont R.J. 1997. The costs of production diseases in dairy herds in England. Veterinary Journal. 154(3): 41-51.

19 König S., Wu X.L., Gianola D., Heringstad B. \& Simianer H. 2008. Exploration of relationships between claw disorders and milk yield in Holstein cows via recursive linear and threshold models. Journal of Dairy Science. 91(1): 395-406.

20 Manske T., Hultgren J. \& Begsten C. 2002. The effect of claw trimming on the hoof health of Swedish dairy cattle. Preventive Veterinary Medicine. 54(2): 113-129.

21 Nishimori K., Okada K., Ikuta K., Aoki O., Sakai T. \& Yasuda J. 2006. The effects of one time trimming on blood biochemical composition, milk yield, and milk composition in dairy cows. Journal of Veterinary Medicine Science. 68(3): 267-270.

22 Shearer J.K. \& van Amstel S.R. 2001. Functional and corrective claw trimming. Veterinary Clinics North America Food Animal Practice. 17(1): 53-72.

23 Sogstad A.M., Fjeldaas T., Osteras O. \& Forshell K.P. 2005. Prevalence of claw lesions in Norwegian dairy cattle housed in tie stalls and free stalls. Preventive Veterinary Medicine. 70(3-4): 191-209.

24 Sogstad A.M., Osteras O., Fjeldaas T. \& Refsdal A.O. 2007. Bovine claw and limb disorders at claw trimming related to milk yield. Journal of Dairy Science. 90(2): 749-759.

25 Somers J.G.C.J., Frankena K., Nordhuizen-Stassen E.N. \& Metz J.H.M. 2003. Prevalence of claw disorders in Dutch dairy cows exposed to several floor systems. Journal of Dairy Science. 86(6): 2082-2093. 
26 Rajala-Schultz P.J., Gröhn Y.T. \& McCulloch C.E. 1999. Effects of milk fever, ketosis, and lameness on milk yield in dairy cows. Journal of Dairy Science. 82(2): 288-294.

27 Van der Tool P.P.J., van der Beek S.S., Metz J.H.M., Noordhuizen-Stassen E.N., Back W., Braam C.R. \& Weijs W.A. 2004. The effect of preventive trimming on weight bearing and force balance on the claws of dairy cattle. Journal of Dairy Science. 87(6): 1732-1738.

28 Van der Waaij E.H., Holzhauer M., Ellen E., Kamphuis C. \& de Jong G. 2005. Genetic parameters for claw disorders in Dutch dairy cattle and correlations with conformation traits. Journal of Dairy Science. 88(10): 3672-3678.

29 Vermunt J.J. \& Greenough P.R. 1994. Predisposing factors of laminitis in cattle. British Veterinary Journal. 150(2): 151-164. 